\title{
THE IMPLEMENTATION OF REGIONAL SPATIAL PLAN POLICY OF REGENCY: A STUDY ON REGIONAL REGULATION \#2 OF YEAR 2011 REGARDING 2010-2030 REGIONAL SPATIAL PLAN IN PARIGI MOUTONG REGENCY
}

\author{
Herman, Sumartono, Hanafi Imam \\ Master's Degree Program of Public Administration, Faculty of Administrative Science, \\ University of Brawijaya, Indonesia \\ E-mail: herman.parimo@gmail.com
}

\begin{abstract}
The implementation of regional spatial plan policy bases on Regional Regulation No.2 of 2011 regarding regional spatial plan in Parigi Moutong regency - the principle of law legality of the regional spatial plan in the urban area of Parigi. The spatial plan policy is implemented because there is a space decrease in both structure and pattern that leads to space narrowing in the urban area. The research used a descriptive-qualitative method and the data were collected by means of observation, interview, and documentation. The research result toward Regional Regulation No.2 of 2011 on the regional spatial plan of Parigi Moutong regency was viewed from the perspective of Grindle model. This model was influenced by the content of the policy of Regional Regulation No. 2 of 2011 regarding the regional spatial plan of Parigi Moutong regency which was concerned with a fact saying that there has not been any implementation of regional spatial plan policy in the capital of Parigi Moutong regency related to the role and function of the society toward the content of the policy itself. Due to the condition, the society tended to become less active in carrying out the policy. As the consequence, it affected the implementation of the regional regulation that made the facility of Ruang Terbuka Hijau (RTH) / Green Open Space, environment cleanliness and greening plants become less well-maintained and managed.
\end{abstract}

\section{Key words}

Policy implementation, regional spatial plan, regional regulation.

Government policy is a decision taken to consider the conditions occurring in society environment, either it has been implemented or not by the government. Prior to implementing a government policy, the condition of a region should be observed. Therefore, it is highly important to carry out the government policy based on the applicable law. The decision is conducted because it has a high-principled law to perform the policy that has been planned previously agree with the expectation and aims that a region wants to achieve. Linear with this, there are some observed problems or conditions of regional spatial plan that occur in the capital of Parigi Moutong regency, covering: (1) the urban space that has not been wellarranged due to space narrowing, (2) the uncontrolled land use, (3) the condition of Green Open Space that is poorly managed, and (4) the scattered waste/trash that makes the environment less clean and tidy.

Those existing kinds of problems need the regional spatial plan policy to minimize the impacts arising and to arrange the space under the procedures that have been determined within it. To overcome the problems, it is extremely significant that the related parties (the government, society and private sectors) can get involved and carry out the policy together. Conversely, the policy may also get ignored due to lack of society participation or less active people that lead the policy to negative sides. As the consequence, this condition is more likely to affect the policy itself that is going to be implemented. Hence, the involvement of the related parties is highly required in performing the policy so that the implementation can be well proceed in line with the stated aims and eventually give positive impacts on the environment and society in the urban area. The policy is committed in order to minimize the environment change. 
According to Webster (in Wahab, 2012:135), the policy implementation can be considered as a process to carry out the decisions made into the policy, commonly in the form of law, government regulation, judicial decisions, executive orders, or presidential decree.

Additionally, Wahab (2012, in Berliahadi (2015:9-10) added that regional spatial plan is a public policy designed by local government which is expected to be implemented and become a reference or guideline for local development. Linear with this, some experts stated that the process of public policy implementation is not only concerned with the behaviour of administrative bodies that are responsible for executing the program and establishing the obedience/compliance of the target groups - including the networks of political, economic, and social forces, both directly or indirectly, which are able to give either positive or negative impact to all the involved parties. Thus, to achieve a good performance in the implementation, all of the involved parties should unite the aims they want to achieve under the commitment to support the activity implementation.

Urban Green Open Space is a part of open space in urban area fulfilled with plants and crops used to promote the ecological, social, cultural, and aesthetic benefits (according to the Regulation of Minister of Domestic Affairs of the Republic of Indonesia (Permendagri) No. 1 of 2007). Furthermore, Jago and Usman (2005:5) revealed that Green Open Space is provided as an ecosystem balancing for either the hydrology, climatology, biodiversity, ecological system or society welfare (quality of life, human well being).

The regional spatial plan (RTRW) of Parigi Moutong regency is regulated under Regional Regulation No.2 of 2011, Law No.23 of 2014 on Local Government, and Law No.26 of 2007 on Spatial Planning. The spatial planning of Parigi Moutong regency is greatly substantial to be done in parallel with the implementation of spatial planning in Indonesia. Spatial planning can be very beneficial for society by considering the significant aspect in conducting the implementation of spatial planning, namely space utilization control.

The research aims to describe and analyze the policy implementation of Regional Regulation No.2 of 2011 of Parigi Moutong regency on the regional spatial Plan of Parigi Moutong regency. Moreover, in this research, the driving and inhibiting factors of the regional spatial plan toward Regional Regulation No.2 of 2011 of Parigi Moutong regency are also outlined and analyzed.

\section{METHODS OF RESEARCH}

This research was conducted by using a descriptive-qualitative method. The focus of this research was describing and analyzing the policy implementation of Regional Regulation No. 2 of 2011 on regional spatial plan (RTRW) of regency based on the perspective of Merilee S.Grindel. Grindel stated that (a) the content of policy includes: interests of target groups, type of benefits, extent of change envisioned, site of decision making, program implementers, and resource used; (b) the context of policy implementation covers: power, interests and strategies of actors involved, institution and regime characteristics, compliance level, as well as society responsiveness; (c) the result of policy consists of the impacts resulted from the policy of regional spatial plan of regency. Additionally, this research was concerned on the driving and inhibiting factors of the regional spatial plan toward Regional Regulation No.2 of 2011 on regional spatial plan (RTRW) of regency.

The research was done in the capital of Parigi Moutong regency, but the research site was focused on the Spatial Planning Division of Parigi Moutong regency. The data of this research consisted of primary and secondary data and the data sources were in the form of: a) informant; b) event/place; c) document. The data were collected by using some techniques, including observation, interview, and documentation (Sugiono, 2015:62). The research instrument was the researcher himself who directly plunged into the field for data collecting which was mostly relied on human instruments. The data of this research were then analyzed using an interactive model of analysis, consisting of: (1) data condensation, (2) data display, and (3) conclusion drawing/verification (Miles, Huberman, and Saldana, 2014:12). 


\section{RESULTS AND DISCUSSION}

The implementation of regional spatial plan (RTRW) policy of Parigi Moutong regency under Regional Regulation No.2 of 2011 on regional spatial plan uses the policy implementation model of Grindle perspective (1980:11). According to Grindle, the success of policy implementation can be influenced by two variables, namely the content of policy and the context of policy, in addition to the result of policy. Both variables have its own indicators. And each indicator can influence the success of policy implementation.

The Content of Regional Spatial Plan Policy. Viewed from each indicator, the content of regional spatial plan policy of Parigi Moutong regency is outlined as follows:

1. The interests of target groups in the regional spatial plan policy. The groups, which were included in the target of the policy implementation of regional regulation regarding the regional spatial plan of Parigi Moutong regency, consisted of society and private groups. These groups acted as the recipient of the policy. Considering that the existing problems are inseparable from the spatial plan or the desire to arrange structure/pattern of a space to be better, it is highly required that all the target groups can contribute and participate together in implementing the policy of Regional Regulation No.2 of 2011 so that the space looks cleaner and tidier. According to Hasan (2015:114), there are three groups of stakeholders playing roles in the implementation of the spatial-detailed plan, including: (1) Government that covers central and local government, (2) Society, and (3) Private parties.

2. The type of benefits. In accordance with the result of observation in the field, the type of benefits accepted by the target groups along with the spatial plan policy indicated that there was still a lot of waste/trash scattered that made the urban space look less clean and less well-managed. Additionally, the greening/afforestation seemed to be infertile and its advantage in relation to the implementation of the spatial plan, including the Urban Green Open Space, was not much felt by the society. According to Grindle (1980), type of benefits has an effort to show and describe that, in a policy, there should be some types of benefits indicating positive impacts resulted by the implementation of the policy that is going to be performed.

3. The extent of change envisioned through the spatial plan policy. The change made by the government on the spatial plan was viewed from the aspects of both road and Green Open Space (Ruang Terbuka Hijau / RTH) constructions, which still experienced obstacle in the term of cleanness. The facility in RTH was also less well-maintained.

4. The site of decision-making on the regional spatial plan policy. The decision-making was based on the problems emerging in the region, namely the less good spatial planning and the decreased urban greening which influenced the environment. The problems were caused by the less controlled-development. According to Grindle (1980), site of decisionmaking of a policy has an important role in its implementation.

5. The implementers of the regional spatial plan policy. The Spatial Planning Agency of Parigi Moutong regency was the one that directly handled and controlled the implementation of the policy toward the spatial plan program in the urban area. According to Udoji (1981, in Wahab, 2012), policy implementation is a very important thing, which is even more important than policy-making. A policy will be no more than good vision or plan that is well-preserved within archive if it is not implemented.

6 . The resources used in the implementation of regional spatial plan policy. The resources used in the implementation of the regional spatial plan policy of Parigi Moutong regency were in the form of human resource, finance, and time. These kinds of resources are very needed for policy implementation since it gives impacts on the policy that will be performed. The resources tend to make the program well-proceed (either in the planning or implementation stage) and can bring the desired results into reality. According to Van Mater and Van Horn (in Nawawi, 2009:139), it is stated that, in an implementation of policy, a support of either human, material, or method resource is very needed.

The Context of Regional Spatial Plan Policy. The context of the implementation of regional spatial plan policy of Parigi Moutong regency (viewed from each indicator) is described as follows: 
1. The power, interest, and strategy of actors involved. In this indicator, the power, interest, and strategy of the policy were fully the right of the implementers given the responsibility to carry out the activities of arranging the less well-managed and less clean spaces in the urban area. The implementers of regional spatial plan policy of Parigi Moutong regency here referred to Public Works Office. According to Abdul Wahab (2011, p.167), the context of policy contains the capabilities, interests, and strategies of involved actors, along with the characteristics of the regime on which they interact each other. In this case, interests also play an important role in the policy implementation. Those intended interests are that the implementers of spatial planning sector can execute programs as the main task and function in its sector. The actors' strategies are highly crucial in the policy implementation. The strategies are done by the actor-acted implementer in order to make the spatial plan proceed well.

2. The characteristics of institution and regime. The institution referred to Public Works Office taking act as the full implementers of the activity program of the policy that would be conducted, namely regional spatial plan of Parigi Moutong regency. In another side, the regime referred to the Regent (Bupati) of Parigi Moutong that was elected directly by the society as the power holder of the region, accompanied with the Vice-Regent as the second power holder or the representative of the Regent.

3. Compliance level and society responsiveness. The compliance level and society responsiveness in the capital of Parigi Moutong regency regarding the existing problems were more likely to be less or low. The less well-managed space planning in the regency was caused by the less active society. This condition occurred since there was a lack of socialization the government should do in relation to the regional spatial plan, primarily in the urban area.

The Result of Regional Spatial Plan Policy. The results of the regional spatial plan policy of Parigi Moutong regency were in the form of resulted impact, change, or society acceptance. In the term of impacts, the policy had led to the decreased space in the urban area that also caused the regency less good-looking. In another side, the change and society acceptance toward the spatial plan policy tended to be good enough. Contrastly, there were still many obstacles in the term of change, such as the facility of Green Open Space (RTH) which was not well-maintained. As for the society acceptance sector, there still needed much more improvement in the term of the use and utilization.

The Driving and Inhibiting Factors of Regional Spatial Plan. In this research, it is found that there were some driving and inhibiting factors of the regional spatial plan of Parigi Moutong regency toward Regional Regulation No.2 of 2011 regarding the regional spatial plan (RTRW) of Parigi Moutong regency. The driving factors of the implementation of regional spatial plan policy in the capital of Parigi Moutong regency included: (1) the existence of regional regulation policy No.2 of 2011 on the regional spatial plan (RTRW) of Parigi Moutong regency, (2) the allocation of new land for spatial planning in the urban area, (3) the cooperation among related institutions/parties that had roles in the implementation of the spatial planning in the urban area.

Meanwhile, the inhibiting factors of the implementation of regional spatial plan policy of the regency consisted of 1 ) The lack of socialization done by the government to the society regarding the spatial plan policy, 2) the lack of society participation regarding the spatial planning in urban area, 3) the less good facility of Green Open Space (RTH), 4) the less maintained greening plants for the environmental preservation in the urban area.

\section{CONCLUSION}

Based on the result and discussion of this research, it is concluded that the implementation of regional spatial plan policy of Parigi Moutong regency tends to be less well-proceed. There are still many obstacles influencing the indicators of the content of the policy carried out by the implementers concerning on the regional spatial plan of the capital of Parigi Moutong regency. In this case, the society participation greatly influences the policy for doing the spatial plan implementation in the field. 
Furthermore, the role and function of society based on the content of the policy have not been yet obviously implemented. This has led the society to be less active in reflecting the policy of regional regulation into their daily practices and playing their roles in accordance with the content of the regional spatial plan policy.

Through this research, it is also discovered that sensitivity toward the content and environment of policy is highly required in the policy implementation - clarifying what is included in the policy as well as implementing it in accordance with the aim of the regional spatial plan policy (RTRW).

The context of the implementation of spatial plan policy is used to find out and comprehend the spatial plan on the environment of policy in the capital of Parigi Moutong regency in which there are some indicators. The first is the power, interests, and strategies of involved actors. The power of policy implementers is on the hand of Public Works Office which is considered as a good implementer of the spatial plan that is also involved as the ruler. This is because Public Works Office can unite the power. The interests of involved actors include the heads of sections, society, and private sectors that have roles in performing the spatial plan policy together. And the strategies of the involved actors (in this term, Public Works Office also acts as the actor) for carrying out the physical development plan in various sectors consist of having coordination with the involved parties, making approach and socialization, as well as doing space improvement by controlling the use of space. The second is the institution carrying out the regional regulation of spatial plan. In this term, the institution is Spatial Planning Division of Public Works Office which is as the implementer that has a pretty good characteristic and democracy for proceeding a rule on the spatial plan in line with the characteristic owned by the institution. The third is the compliance level and the more responsiveness of the implementers, which in this term are society, for carrying out the spatial plan in the urban area. This indicator can give positive impacts for the implementation of policy. The higher the compliance and responsiveness levels of the implementers are, the more positive chance the urban environment will achieve.

In the term of the result of regional spatial plan policy, it is expected that the implementation of the spatial plan policy can be beneficial for the society which is not only in the sector of construction but also in the term of social improvement. In the social improvement, the policy is required to be developed so that the result and benefit can be sustainably felt by the society, either in the now or in the future. Based on the results of observation and interview done by the researcher, it can be concluded that the results of the policy that has been carried out by the implementers of the spatial plan activity proceed pretty well in the development sector. Furthermore, the change and society acceptance of the results of policy also give positive impacts in the term of development/construction. However, the society has not yet felt its benefits, either in the term of the facility of Green Open Space or the urban cleanliness itself.

As for the driving factors of the implementation of spatial plan policy, the existence of regional regulation has provided a stronger legality to carry out the policy in which Public Works Office acts as the implementator of the policy itself. The allocation of new land facilitates the process of spatial planning in the capital of Parigi Moutong regency. The society can utilize the allocation by building up a place for public space. Additionally, the cooperation of the related institutions regarding the spatial plan in the urban area is greatly important for the process of policy implementation toward the activity program. A cooperation with Regional Planning Agency of Parigi Moutong regency - an agency handling the stages of plan process - is made by Public Works Office for the spatial planning of the capital of Parigi Moutong regency.

In another side, the inhibiting factors of the implementation of spatial plan policy include the lack of socialization done by the government in relation to the regional regulation on the regional spatial plan. This factor can lead the spatial plan policy to trigger negative impacts toward the spatial planning in the urban area. In addition to the lack of socialization, the other inhibiting factor emerging is the lack of society participation on the spatial planning. This factor also highly influences the implementation process of spatial plan policy. Furthermore, the less good facility of Green Open Space (RTH) also affects the public comfort toward the 
facilities of spatial planning in the urban area. In this term, there are still many problems which result in the less well-maintained facility in RTH. Two of the problems include the cleanliness not being noticed and the less groomed greening plants for the environmental preservation in the urban area. The less groomed plants are caused by the negligence of people who deliberately destroy it yet are not responsible for their disservice. Besides, the people's farm animals also cause the plants damaged and die.

\section{REFERENCES}

1. Adisasmita, Rahardjo. 2013. Pembangunan Kawasan dan Tata Ruang. Cetakan kedua Penerbit Graha IImu, Yogyakarta.

2. Budiharjo, Eko. 2005. Tata Ruang Perkotaan, Penerbit Alumni, Bandung.

3. Barliahadi, Deden. 2015. "Implementasi Perda Nomor 2 Tahun 2012 Tentang Rencana Tata Ruang Wilayah Kabupaten Lombok Timur Tahun 2012-2032 Dalam Perspektif Pengendalian Pemanfaatan Ruang. Jurnal Reformasi Vol. 5, No.1,

4. Dunn, William N. 2003. Pengantar Analisis Kebijakan Publik, Edisi Kedua, Gadjah Mada University Press, Yogyakarta.

5. Grindle, Marilee S. 1980. Politics and Policy Implentation inthe Word (New Jersey: Princeton University Press.

6. Moleong, J. Lexy. 2015. Metodologi Penelitian Kualitatif, PT. Remaja Rosdakarya, Cetakan Tiga Puluh Empat, Bandung.

7. Mazmanian, Daniel, dan Paul A Sabtier, (eds). 1981. Effective Policy Implemntation. Lexington, Mass, D.C.: Heath.

8. Hasan, 2015. Menata Kota Melalui Rencana Detail Tata Ruang (RDTR). Andi, Anggota IKAPI, Yogyakarta.

9. Irwan, Djamal. 2008. Tantangan Lingkungan dan Langsekap Hutan Kota, Cetakan Kedua, Bumi Aksara, Jakarta.

10. Miles, Matthew B, A. Michael Huberman dan Johnny Saldana. 2014. Qualitative Data Analysis, A Methods Sourcebook Edisi Ketiga, Sage Publication:Inc.

11. Nawawi, Ismail. 2009. Analisis, Strategi Advokasi Teori dan Praktek. Penerbitan Pertama, CV. Putra Media Nusantara, Surabaya.

12. Sugiyono. 2015. Memahami Penelitian Kualitatif. Cetakan Ke Sebelas, Alfabeta, Bandung.

13. Suharno. 2013. Dasar-Dasar Kebijakan Publik: Kajian Proses Dan Analisis Kebijakan. Cetakan Pertama, Penerbit Ombak (Anggota IKAPI), Yogyakarta

14. Wahab, A. 2012. Analisis Kebijakan: dari Formulasi Ke Implementasi Kebijaksanaan, Cetakan Pertama, PT. Bumi Aksara, Jakarta. 